\title{
Management and outcome of patients with established coronary artery disease: the Euro Heart Survey on coronary revascularization
}

\author{
M.J. Lenzen ${ }^{1}$, E. Boersma ${ }^{1}$, M.E. Bertrand ${ }^{2}$, W. Maier ${ }^{3}$, C. Moris ${ }^{4}$, F. Piscione ${ }^{5}$, \\ U. Sechtem ${ }^{6}$, E. Stahle ${ }^{7}$, P. Widimsky ${ }^{8}$, P. de Jaegere ${ }^{1}$, \\ W.J.M. Scholte op Reimer ${ }^{1}$, N. Mercado ${ }^{1}$, and W. Wijns ${ }^{9 *}$ \\ ${ }^{1}$ Department of Cardiology, Erasmus MC, Thoraxcenter, Rotterdam, The Netherlands \\ ${ }^{2}$ Division of Cardiology, Lille University Heart Institute, Lille, France \\ ${ }^{3}$ Department of Cardiology, University Hospital Zurich, Zurich, Switzerland \\ ${ }^{4}$ Cardiology Service, Hospital Central de Asturias, Asturias, Spain \\ ${ }^{5}$ Division of Cardiology, Federico II University, Naples, Italy \\ ${ }^{6}$ Department of Cardiology, Robert-Bosch-Krankenhaus, Stuttgart, Germany \\ ${ }^{7}$ Thoracic and Cardiovascular Surgery, University Hospital, Uppsala, Sweden \\ ${ }^{8}$ University Hospital Vinohrady, Prague, Czech Republic \\ ${ }^{9}$ Cardiovascular Centre, OLV Hospital, 164 Moorselbaan, B 9300 Aalst, Belgium
}

Received 6 December 2004; revised 10 February 2005; accepted 23 February 2005; online publish-ahead-of-print 31 March 2005

See page 1147 for the editorial comment on this article (doi:10.1093/eurheartj/ehi247)

\section{KEYWORDS}

Coronary artery disease;

Coronary angiography;

CABG;

$\mathrm{PCl}$;

Practice survey

\begin{abstract}
Aims The purpose of the Euro Heart Survey Programme of the European Society of Cardiology is to evaluate to which extent clinical practice endorses existing guidelines as well as to identify differences in population profiles, patient management, and outcome across Europe. The current survey focuses on the invasive diagnosis and treatment of patients with established coronary artery disease (CAD).

Methods and results Between November 2001 and March 2002, 7769 consecutive patients undergoing invasive evaluation at 130 hospitals (31 countries) were screened for the presence of one or more coronary stenosis $>50 \%$ in diameter. Patient demographics and comorbidity, clinical presentation, invasive parameters, treatment options, and procedural techniques were prospectively entered in an electronic database (550 variables +29 per diseased coronary segment). Major adverse cardiac events (MACE) were evaluated at 30 days and 1 year. Out of 5619 patients with angiographically proven coronary stenosis ( $72 \%$ of screened population), $53 \%$ presented with stable angina while ST elevation myocardial infarction (STEMI) was the indication for coronary angiography in 16\% and non-ST segment elevation myocardial infarction or unstable angina in $30 \%$. Only medical therapy was continued in $21 \%$, whereas mechanical revascularization was performed in the remainder [percutaneous coronary intervention $(\mathrm{PCI})$ in $58 \%$ and coronary artery bypass grafting (CABG) in $21 \%$. Patients referred for $\mathrm{PCl}$ were younger, were more active, had a lower risk profile, and had less comorbid conditions. CABG was performed mostly in patients with left main lesions $(21 \%)$, two- $(25 \%)$, or three-vessel disease $(67 \%)$ with 4.1 diseased segments, on average. Single-vessel $\mathrm{PCl}$ was performed in $82 \%$ of patients with either
\end{abstract}

* Corresponding author. Tel: +32 53724439; fax: +32 53724185

E-mail address: william.wijns@olvz-aalst.be 
single- $(45 \%)$, two- $(33 \%)$, or three-vessel disease $(21 \%)$. Stents were used in $75 \%$ of attempted lesions, with a large variation between sites. Direct PCI for STEMI was performed in 410 cases, representing $7 \%$ of the entire workload in the participating catheterization laboratories. Time delay was within $90 \mathrm{~min}$ in $76 \%$ of direct $\mathrm{PCl}$ cases. In keeping with the recommendations of practice guidelines, the survey identified under-use of adjunctive medication (GP Ilb/Illa receptor blockers, statins, and angiotensin-converting enzyme-inhibitors). Mortality rates at 30 days and 1 year were low in all subgroups. MACE primarily consisted of repeat PCI (12\%).

Conclusion The current Euro Heart Survey on coronary revascularization was performed in the era of bare metal stenting and provides a global European picture of the invasive approach to patients with CAD. These data will serve as a benchmark for the future evaluation of the impact of drug-eluting stents on the practice of interventional cardiology and bypass surgery.

\section{Introduction}

The management of patients with coronary artery disease $(C A D)$ is complex. Better understanding of the pathophysiology of the disease and the introduction of novel diagnostic techniques in conjunction with novel or more powerful pharmacologic and revascularization therapies mandate continuous reassessment and evaluation of medical practice. ${ }^{1-6}$

Practice guidelines for diagnostic procedures and patient management are established to help cardiologists in every-day clinical decision making. The scientific foundation for these guidelines is provided by randomized clinical trials, although non-randomized trials, retrospective studies, or consensus opinion of experts are also used. ${ }^{7-9}$

The European Society of Cardiology (ESC) is dedicated to improve health by reducing the impact of cardiovascular disease by various means. The Euro Heart Survey programme is meant to evaluate to which extent clinical practice endorses existing guidelines as well as to identify differences in population profiles, patient management, and outcome across Europe. ${ }^{10}$

The current survey focuses on patients with at least one $>50 \%$ diameter stenosis, visualized during coronary angiography, who are potential candidates for coronary revascularization.

\section{Methods}

The Euro Heart Survey on coronary revascularization was conducted in 130 voluntary participating hospitals from 31 ESC member countries, with the objective to evaluate clinical practice, adherence to guidelines, differences in the management, and outcome of patients and to assess to what extent the patients of daily practice are represented in randomized clinical trials. Participating hospitals represent both academic (40\%) and non-academic $(60 \%)$ institutions with $(83 \%)$ and without $(17 \%)$ cardiac surgery and/or interventional cardiology facilities. These centres were asked to enrol blocks of 40 consecutive patients. The present survey was designed to screen all consecutive patients undergoing invasive diagnostic or therapeutic catheterization, of which all patients with $>50 \%$ diameter stenoses in at least one major epicardial vessel were asked to participate. In each hospital, data (550 patient variables and 29 variables per treated coronary segment) were collected by data collecting officers on computers, using the Macro $^{\mathrm{TM}}$ software (InferMed, UK) and sent through the internet to a central database located at the European Heart House. The software used implemented internal edit checks for missing or contradictory entries or for values out of the normal range. The data management staff of the European Heart House performed additional edit checks. Canadian Class Society (CCS) functional class and risk stratification were evaluated prospectively in patients with stable angina. ${ }^{11,12}$ The EuroSCORE and TIMI risk score were calculated from the available variables. ${ }^{13,14}$

The survey on coronary revascularization was conducted between November 2001 and March 2002. One year follow-up was made by personal or telephone contact and available in 4770 patients $(83 \%)$. Fourteen hospitals $(11 \%)$ were not able to provide follow-up information. Median (quartiles) follow-up period was 12 months (11-13 months). Statistical analyses were carried out with SPSS statistical software (version 12.0 for Windows), using mostly descriptive statistics between subsets of patients defined by treatment preference. Results are presented as mean and median with corresponding values (SD and inter-quartile ranges, respectively) and as per cent. Given the large sample size, $P$-value of $\leq 0.001$ was considered statistically significant.

\section{Results}

A total of 7769 patients undergoing coronary angiography were screened, of whom 5767 fulfiled the inclusion criteria. Patients with either insufficient or invalid data ( $n=148$ ) were excluded from further analysis. Therefore, the total population of the present report amounts to 5619. The baseline characteristics are summarized in Table 1. Stable angina was the most frequent indication to perform angiography (53\%), followed by non-ST segment elevation myocardial infarction (NSTEMI) or unstable angina (UA) (30\%) and ST elevation myocardial infarction (STEMI) (16\%). In 2002 of the screened patients $(24 \%)$, no CAD or stenosis $<50 \%$ was found. Absence of significant $C A D$ differed between patients with acute coronary syndrome (ACS) $(16 \%)$ and stable ischaemic heart disease $(35 \%)$ but was most prevalent when CAD was not the primary reason for performing angiography $(48 \%)$. 
Table 1 Clinical characteristics of total cohort and patients in different treatment groups

\begin{tabular}{|c|c|c|c|c|c|}
\hline & $\begin{array}{l}\text { Total } \\
(n=5619)\end{array}$ & $\begin{array}{l}\mathrm{PCl} \\
(n=3254)\end{array}$ & $\begin{array}{l}\text { CABG } \\
(n=1188)\end{array}$ & $\begin{array}{l}\text { Medical } \\
(n=1177)\end{array}$ & $P$-value \\
\hline Age (mean $\pm S D$ ) & $63.2 \pm 10.8$ & $62.4 \pm 11.2$ & $64.5 \pm 10.0$ & $64.3 \pm 10.6$ & * \\
\hline Male gender, $n(\%)$ & $4268(76)$ & $2448(75)$ & $933(\overline{79})$ & $887(\overline{75})$ & \\
\hline \multicolumn{6}{|l|}{ Smoking, $n(\%)$} \\
\hline Current & $1411(25)$ & $912(28)$ & $262(22)$ & $237(20))$ & \\
\hline Past & 1924 (34) & $1045(32)$ & $434(37)$ & $445(38)$ & * \\
\hline Never & $2084(37)$ & $1170(36)$ & $452(38)$ & 462 (39) & \\
\hline \multicolumn{6}{|l|}{ Diabetes mellitus, $n(\%)$} \\
\hline Type 1 & $208(4)$ & $121(4)$ & $38(3)$ & $49(4)$ & \\
\hline Type 2 & $1130(20)$ & $603(19)$ & $261(22)$ & $266(23)$ & \\
\hline Hypercholesterolaemia, $n$ (\%) & $3591(65)$ & $2130(67)$ & 737 (64) & $724(64)$ & \\
\hline Hypertension, $n(\%)$ & $3315(60)$ & $1851(57)$ & $714(61)$ & $750(64)$ & * \\
\hline Sedentary lifestyle, $n$ (\%) & $1601(40)$ & $869(37)$ & $357(43)$ & $375(45)$ & * \\
\hline Congestive heart failure, $n(\%)$ & $1026(18)$ & 457 (14) & $279(24)$ & $290(25)$ & * \\
\hline Chronic lung disease, $n(\%)$ & $492(9)$ & $273(8)$ & $106(9)$ & $113(10)$ & \\
\hline Chronic renal failure, $n$ (\%) & $226(4)$ & $137(4)$ & $33(3)$ & $56(5)$ & \\
\hline Peripheral vascular disease, $n(\%)$ & $657(12)$ & $330(10)$ & $169(14)$ & $158(14)$ & * \\
\hline Cerebrovascular disease, $n(\%)$ & $427(8)$ & $205(6)$ & $116(10)$ & $106(9)$ & * \\
\hline Comorbidity per patient $^{\mathrm{a}}($ mean $\pm \mathrm{SD})$ & $0.5 \pm 0.8$ & $0.4 \pm 0.7$ & $0.6 \pm 0.8$ & $0.6 \pm 0.8$ & * \\
\hline Risk factors per patient ${ }^{\mathrm{b}}$ (mean $\pm \mathrm{SD}$ ) & $2.1 \pm 1.0$ & $2.1 \pm 0.9$ & $2.1 \pm 1.0$ & $2.1 \pm 1.0$ & \\
\hline Prior CABG, $n(\%)$ & $601(11)$ & $307(10)$ & $41(4)$ & $253(22)$ & * \\
\hline Prior $\mathrm{PCI}, n(\%)$ & $1140(20)$ & $738(23)$ & $130(11)$ & $272(23)$ & * \\
\hline Prior MI, $n(\%)$ & 2258 (39) & $1168(36)$ & $448(38)$ & $542(47)$ & $*$ \\
\hline \multicolumn{6}{|l|}{ Diagnosis at admission, $n(\%)$} \\
\hline Stable angina & $2936(53)$ & 1503 (47) & $743(64)$ & $690(61)$ & \\
\hline Non-ST elevation ACS/UA & $1672(30)$ & $1014(31)$ & $331(28)$ & 327 (29) & * \\
\hline ST elevation MI & $906(16)$ & $710(22)$ & $88(8)$ & J (10) 108 & \\
\hline $\begin{array}{l}\text { Duration of hospitalization in days } \\
(\text { (median-IQR) })^{\mathrm{C}}\end{array}$ & $5(3-11)$ & $4(3-8)$ & $12(7-22)$ & $4(2-10)$ & * \\
\hline
\end{tabular}

Proportions are given per column. Asterisks denote $P \leq 0.001 ; \mathrm{Ml}$, myocardial infarction.

${ }^{a}$ Comborbidity included congestive heart failure, chronic lung disease, renal failure, peripheral vascular disease, and cerebrovascular disease.

${ }^{\mathrm{b}}$ Risk factors included, smoking (ever), diabetes, hypercholestaerolaemia, and hypertension.

'Data known in 5291 cases (3142 PCI, 1102 CABG, 1047 Medical).

Mechanical revascularization [percutaneous coronary intervention ( $\mathrm{PCl}$ ): 58\%, CABG: 21\%] was often performed or planned, whereas a substantial number of patients were continued on medical treatment $(21 \%)$. $\mathrm{PCl}$ was predominantly performed in patients admitted with ACS with or without ST-segment elevation or UA (53\%), whereas CABG and medical treatment were applied mostly in patients with stable angina (64 and 61\%, respectively). Patients who underwent $\mathrm{PCl}$ were, in general, younger, more active, and with fewer comorbid conditions. Patients who received medical therapy had a higher prevalence of previous bypass surgery and myocardial infarction (Table 1).

Of all diseased segments at coronary angiography (15 856), 51\% was considered suitable for $\mathrm{PCl}$ and $69 \%$ for CABG, whereas $24 \%$ of the lesions (1597 patients) were judged as only suitable for CABG, not for $\mathrm{PCl}$. Most of the lesions unsuitable for $\mathrm{PCl}$ were totally occluded $(70 \%)$ or located in the left main $(20 \%) . \mathrm{PCI}$ was predominantly performed in patients with singlevessel disease and preserved ventricular function (Table 2). Nonetheless, two- and three-vessel disease was present in 33 and 21\%, respectively, suggesting incomplete revascularization by anatomy. Single-PCI was performed in $82 \%$ of all cases and the attempted lesions were of type $A$ in $15 \%, B$ in $50 \%$, and $C$ in $12 \%$. Bypass surgery was mainly performed in patients with three-vessel disease (67\%), left main stem stenosis, $(21 \%)$ or extensive disease as reflected by the mean number of diseased segments (4.1). The left anterior descending coronary artery (LAD) was diseased in $90 \%$ of all patients undergoing CABG and extracorporeal circulation was used in $81 \%$ of all operations.

Patients who received only medical therapy had a higher prevalence of advanced disease when compared with $\mathrm{PCl}$ patients (61 vs. 54\% multi-vessel disease, 2.9 vs. 2.3 diseased segments). Angiographic profile was worst in those who underwent CABG (92\% multi-vessel disease, 4.1 diseased segments). It is worth noting that patients treated medically had the highest prevalence of poor ventricular function. Although the reason for choosing medical treatment was largely related to the clinical presentation and the severity and extent of CAD, we also observed large differences in treatment options between participating hospitals (Figure 1). Apart from contraindications for mechanical revascularization (i.e. vessels not suitable: $34 \%$; high-risk procedure: $17 \%), 13 \%$ of the medically treated patients had refused mechanical revascularization. 
Table 2 Angiographic results based on chosen treatment option

\begin{tabular}{|c|c|c|c|c|c|}
\hline & $\begin{array}{l}\text { Total } \\
(n=5619)\end{array}$ & $\begin{array}{l}\mathrm{PCl} \\
(n=3254)\end{array}$ & $\begin{array}{l}\text { CABG } \\
(n=1188)\end{array}$ & $\begin{array}{l}\text { Medical } \\
(n=1177)\end{array}$ & $P$-value \\
\hline \multicolumn{6}{|l|}{ Severity of CAD, $n(\%)^{a}$} \\
\hline Single-vessel disease & $2010(36)$ & $1469(45)$ & $87(7)$ & $454(39)$ & \\
\hline Two-vessel disease & $1701(30)$ & $1086(33)$ & $298(25)$ & $317(27)$ & * \\
\hline Three-vessel disease & $1882(34)$ & $687(21)$ & $797(67)$ & $398(34)$ & \\
\hline Left main lesions & $476(9)$ & $126(4)$ & $251(21)$ & $99(8)$ & $*$ \\
\hline \multicolumn{6}{|l|}{ Diseased segments } \\
\hline Mean number of diseased segments, SD & $2.8 \pm 1.9$ & $2.3 \pm 1.7$ & $4.1 \pm 1.9$ & $2.9 \pm 2.1$ & $*$ \\
\hline$\%$ valued as suitable for $\mathrm{PCl}$ & 51 & 69 & 37 & 32 & $*$ \\
\hline$\%$ valued as suitable for CABG & 69 & 63 & 91 & 52 & $*$ \\
\hline Left ventricular function known, $n$ (\%) & $4854(86)$ & $2732(84)$ & $1096(92)$ & $1026(87)$ & \\
\hline Ejection fraction $>50 \%$ & $2904(60)$ & $1726(63)$ & $633(58)$ & $545(53)$ & \\
\hline Ejection fraction $40-50 \%$ & $1281(26)$ & $710(26)$ & $295(27)$ & $276(27)$ & * \\
\hline Ejection fraction $<40 \%$ & $669(14)$ & $296(11)$ & $168(15)$ & $205(20)$ & \\
\hline $\begin{array}{l}\text { Intervention performed within } \\
30 \text { days after angiography, } n \text { (\%) }\end{array}$ & 3339 & $2744(84)$ & $595(50)$ & - & \\
\hline $\begin{array}{l}\text { Total number of attempted } \\
\text { segments/diseased segments }\end{array}$ & 5426 & $3564 / 6477(55)$ & $1862 / 2483(75)$ & $-/ 3404(0)$ & \\
\hline Attempted segments per patient, mean ${ }^{\mathrm{b}}$ & - & 1.30 & 3.13 & - & \\
\hline Successfully dilated/bypassed segments $(\%)^{\mathrm{b}}$ & - & 95 & 96 & - & \\
\hline \multicolumn{6}{|l|}{ Procedural techniques } \\
\hline Stenting $(\%)^{\mathrm{b}}$ & - & $2050(75)$ & - & - & \\
\hline One or more arterial graft $(\%)^{b}$ & - & - & $531(89)$ & - & \\
\hline
\end{tabular}

In conjunction with the differences in baseline characteristics, the total and average number of attempted segments differed between $\mathrm{PCl}$ - and CABG-treated patients (Table 2). The large majority of patients undergoing $\mathrm{PCl}$ (84\%) was treated within 30 days, whereas only $50 \%$ of CABG patients were treated within this period. The majority of patients undergoing $\mathrm{PCl}(59 \%)$ underwent the procedure within $24 \mathrm{~h}$ after diagnostic angiography. There was a strikingly high use of stents (applied in 72\% of all attempted segments and $75 \%$ of $\mathrm{PCl}$ patients) while at least one arterial graft was implanted in $89 \%$ of the surgical procedures. The variation in the use of stents in participating hospitals was huge as illustrated in Figure 2. The assessment of procedure-related myocardial injury from serial sampling of necrosis markers was only performed in $61 \%$ of $\mathrm{PCl}$ and $31 \%$ of CABG cases. In accordance with guidelines, consensus statements and data from clinical trials, $\mathrm{PCl}$ patients at increased risk (diabetes, ACS) should receive periprocedural GP Ilb/IIla receptor blockers. GP Ilb/IIla receptor blockers were used only in $27 \%$ of all $\mathrm{PCl}$ procedures. Almost half $(46 \%)$ of all STEMI patients undergoing primary $\mathrm{PCl}(n=393)$ were treated with GP IIb/IIla receptor blockers. In NSTEMI/UA patients undergoing $\mathrm{PCl}$ within 30 days after angiography, $32 \%$ received GP Ilb/Illa receptor blockers, mostly because of high-risk features $(60 \%)$. Among $\mathrm{PCl}$ patients with stable angina, $14 \%$ received GP IIb/IIla receptor blockers and 23\% were on thienopyridine treatment prior to the intervention. No difference in GP IIb/IIla receptor blocker use was observed between patients with or without diabetes mellitus. Furthermore, we observed large differences in the use of GP IIb/IIla receptor blockers between the participating hospitals (Figure 3 ).

In most patients with stable angina, CCS was known (96\%). Almost two-thirds of these patients were in CCS class 1 or 2 (Table 3 ). Patients in CCS 3 or 4 were more likely to be classified as high-risk patients when compared with patients in CCS 1 or 2 (23 vs. 13\%). Comparison of this risk stratification with the EuroSCORE revealed a mean score of 3.3 in low-risk patients, 3.7 in intermediate-risk patients, and 4.4 in high-risk patients. When calculating the EuroSCORE per treatment-group in patients with stable angina and NSTEMI/UA, we observed a lower risk in $\mathrm{PCl}$ patients when compared with CABG and medically treated patients (Table 4). In NSTEMI/UA patients, the TIMI score was similar among the three treatment options (mean score $3.1 \pm 1.1$ ). Despite the proven CAD, a normal ECG was present in $23 \%$ of all NSTEMI/UA cases.

High-risk features or recurrent/persistent angina in NSTEMI/UA patients and recurrent ischaemia or complications in STEMI patients were the most frequent indications for angiography (62 and 42\%, respectively). Cardiogenic shock was registered in $8 \%$ of STEMI patients. The rate of reperfusion therapy including fibrinolytic treatment and primary $\mathrm{PCl}$ in this selected group of STEMI patients who reached the catheterization laboratory was $64 \%$, of which $68 \%$ underwent primary $\mathrm{PCl}$. The median time from admission to the intervention was $45 \mathrm{~min}$ (inter-quartile range: $15-90 \mathrm{~min}$ ) and the procedure started within 90 min after admission in $76 \%$, 
Treatment of patients with coronary artery stenosis $>50 \%$

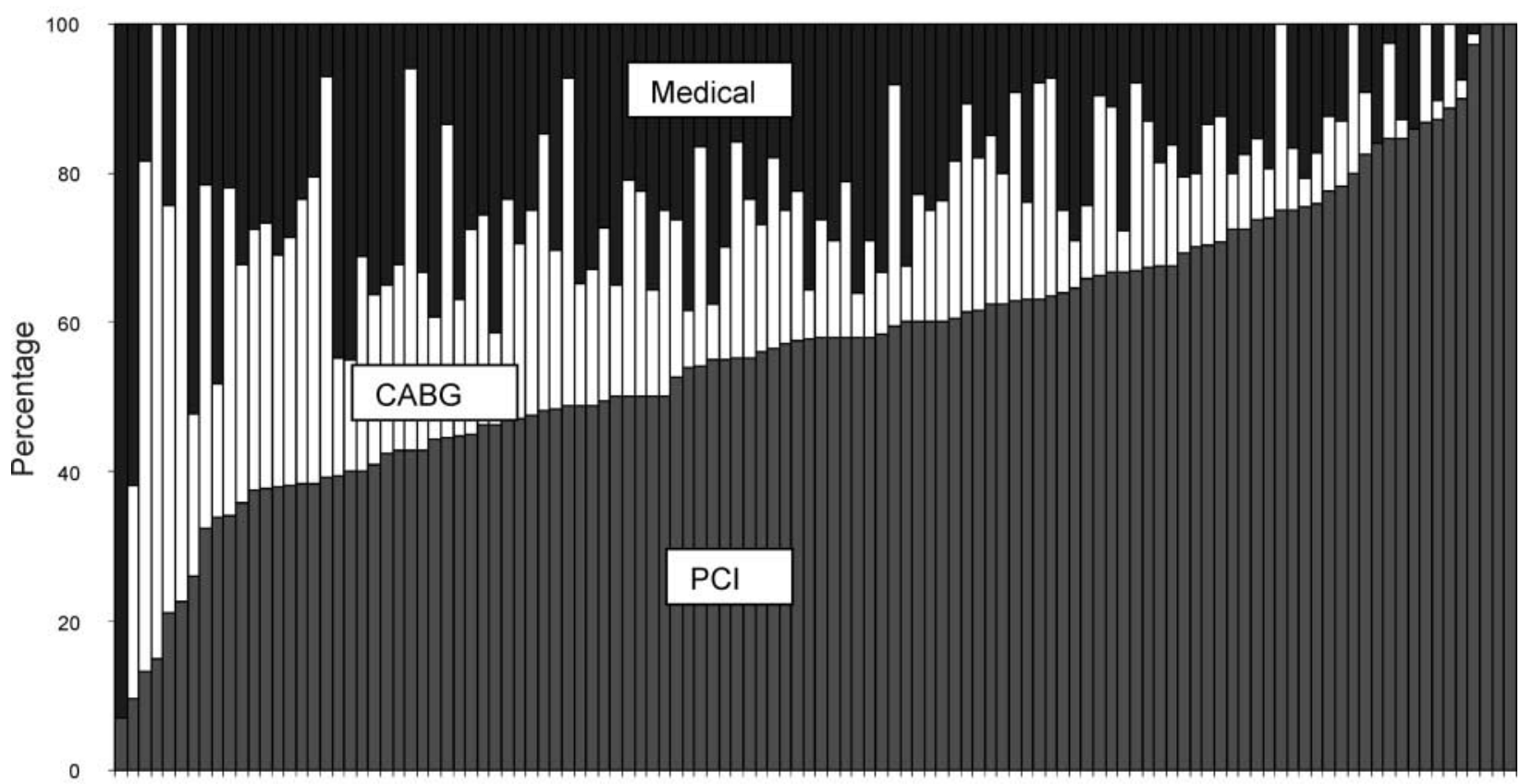

Hospital

Figure 1 Visualizes the per cent of invasive (PCI and CABG) and medically treated patients in hospitals participating in the Euro Heart Survey on coronary revascularization. Hospitals are ordered on the basis of patients referred for $\mathrm{PCl}$. It should be noted that the ordering of hospital differs between the three figures.

\section{Use of stenting}

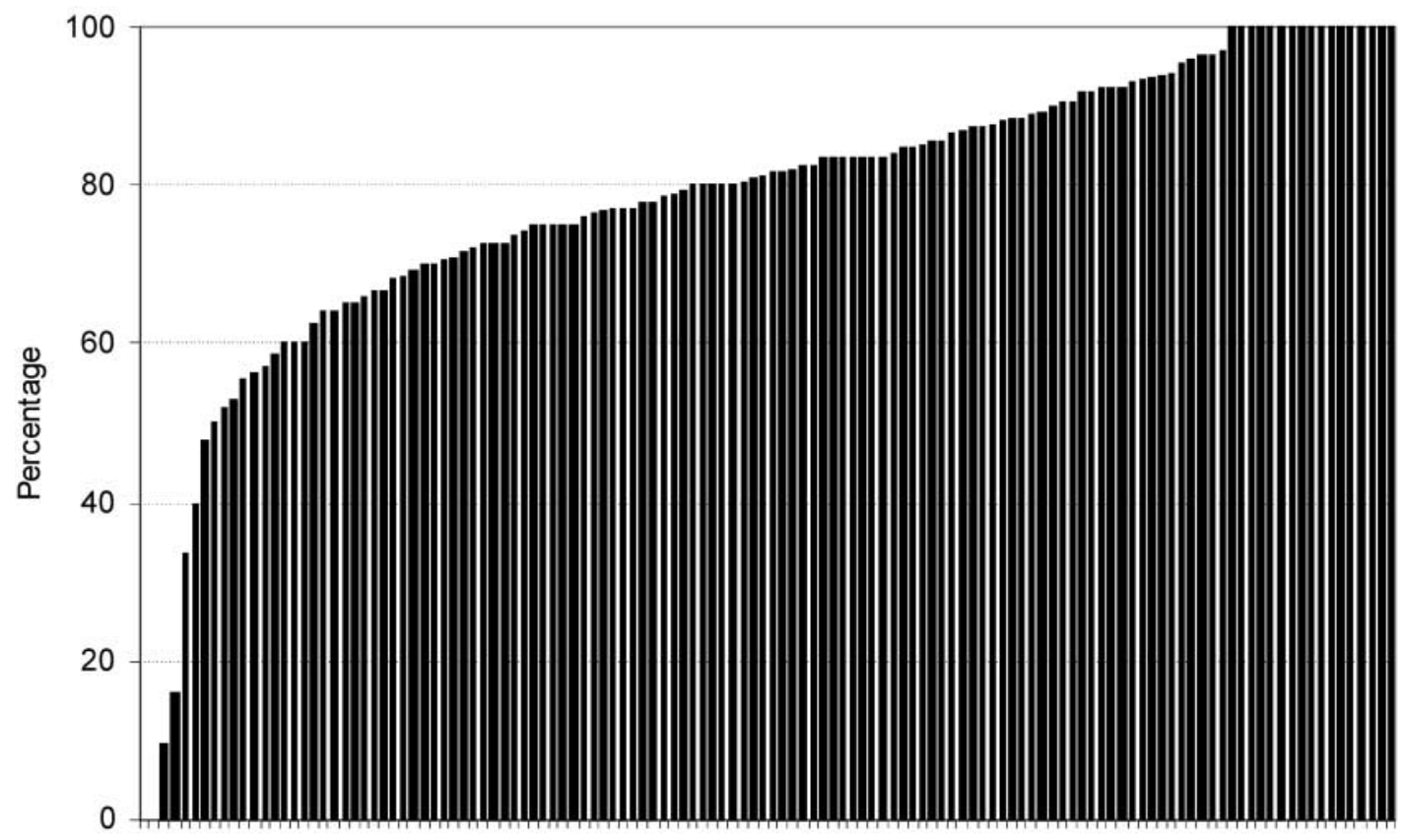

Hospital

Figure 2 The variation in use of stents per hospital in patients who underwent PCI within 30 days after diagnostic angiography. It should be noted that the ordering of hospital differs between the three figures. 


\section{GPIlb/llla inhibitors in $\mathrm{PCI}$ patients}

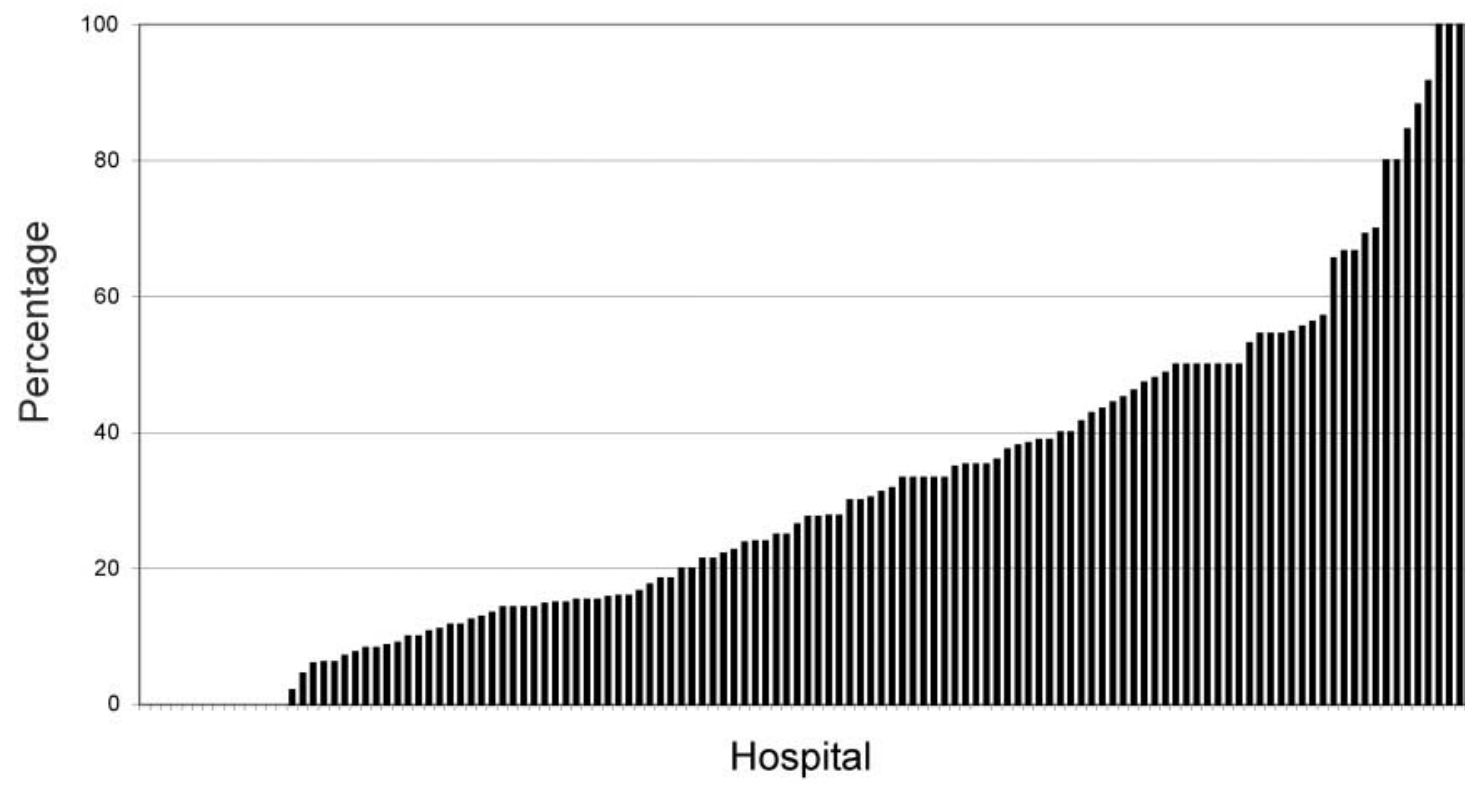

Figure 3 The variation in the use of GP Ila/IIlb receptor blockers stents per hospital in patients who underwent PCI within 30 days after diagnostic angiography. It should be noted that the ordering of hospital differs between the three figures.

Table 3 Risk assessment and outcome in patients with stable angina

\begin{tabular}{|c|c|c|c|c|}
\hline Estimated risk of Canadian class & $\begin{array}{l}\text { Total } \\
2936(53)\end{array}$ & $\begin{array}{l}1 \text { year } \\
\text { mortality }\end{array}$ & $\begin{array}{l}1 \text { year mortality/ } \\
\text { non-fatal MI }\end{array}$ & $\begin{array}{l}1 \text { year mortality/non-fatal MI/ } \\
\text { rehospitalization for cardiac reason }\end{array}$ \\
\hline CCS 1 or $2, n(\%)$ & $1795(63)$ & & & \\
\hline Unknown & $203(11)$ & $5(3)$ & $9(4)$ & $51(25)$ \\
\hline Low (<1\% annual mortality) & $536(30)$ & $14(3)$ & $22(4)$ & $108(20)$ \\
\hline Intermediate (1-3\% annual mortality) & $818(46)$ & $16(2)$ & $27(3)$ & 156 (19) \\
\hline High ( $>3 \%$ annual mortality) & $238(13)$ & $10(4)$ & $13(6)$ & $59(25)$ \\
\hline $\operatorname{CCS} 3$ or $4, n(\%)$ & $1037(37)$ & & & \\
\hline Unknown & $144(14)$ & $7(5)$ & $10(7)$ & $35(24)$ \\
\hline Low ( $<1 \%$ annual mortality) & $158(15)$ & $8(5)$ & $10(6)$ & $42(27)$ \\
\hline Intermediate (1-3\% annual mortality) & $496(48)$ & $18(4)$ & $26(5)$ & $120(24)$ \\
\hline High ( $>3 \%$ annual mortality) & $239(23)$ & $18(8)$ & $20(8)$ & $69(29)$ \\
\hline
\end{tabular}

Proportions are given per row.

Values in parentheses are percentages.

indicating that the majority of patients was treated within the advocated timeframe of $90 \mathrm{~min}$. It should be noted, however, that no information on in-hospital time delay was available in $28 \%$ of patients. Delayed angiography was performed on a systematic basis in $44 \%$ of the 513 STEMI patients who did not undergo primary $\mathrm{PCl}$.

Of the 5619 participating patients, 1.9\% (104 patients) died within 30 days. The overall 1 year mortality was 4.7\% (263 patients). The mortality differed between diagnosis and treatment groups (Table 4). One-year mortality was lowest in patients with stable angina who underwent $\mathrm{PCl}(1.9 \%)$ and highest in STEMI patients not undergoing mechanical revascularization (8.4\%). However, a significantly reduced 1 year mortality between the three treatment groups was observed only in patients with stable angina, reflecting the large proportion of low-risk patients undergoing $\mathrm{PCl}$.

After 1 year, $13 \%$ of the $\mathrm{PCl}$ patients required repeat revascularization $(10 \%$ at least one repeat $\mathrm{PCI}, 3 \%$ were operated), whereas only $1 \%$ of patients initially treated with CABG needed repeat revascularization. A small proportion of patients who were initially treated medically underwent mechanical revascularization eventually (4\%). Rehospitalization for cardiac reasons was more frequent in $\mathrm{PCl}$ and medical patients (28 and $25 \%$, respectively), when compared with those undergoing CABG (15\%).

At discharge, most patients ( $>90 \%$ ) were prescribed at least one anti-thrombotic drug (either aspirin, thienopyridine, or anticoagulants), irrespective of treatment 
Table 4 Risk assessment and outcome in three different diagnosis groups, based on treatment option

\begin{tabular}{|c|c|c|c|c|c|}
\hline & Total & $\mathrm{PCl}$ & CABG & Medical & $P$-value \\
\hline Stable angina, $n$ & 2936 & 1503 & 743 & 690 & \\
\hline Duration of hospitalization in days (median-IQR) & $3(2-9)$ & $3(2-5)$ & $10(5-18)$ & $3(2-6)$ & * \\
\hline EuroSCORE (mean $\pm S D)$ & $3.8 \pm 2.7$ & $3.3 \pm 2.4$ & $4.4 \pm 3.0$ & $4.2 \pm 2.6$ & * \\
\hline 30 day mortality, $n(\%)$ & $25(1)$ & $5(0)$ & $17(2)$ & $3(0)$ & * \\
\hline Total mortality at 1 year, $n(\%)$ & $101(3)$ & $28(2)$ & $41(6)$ & $32(5)$ & * \\
\hline Non-fatal $\mathrm{MI}^{\mathrm{a}}, n(\%)$ & $41(2)$ & $24(2)$ & $8(1)$ & $9(2)$ & \\
\hline Rehospitalization for cardiac reason ${ }^{\mathrm{a}}, n(\%)$ & $559(24)$ & $354(29)$ & $80(14)$ & $125(23)$ & * \\
\hline (Repeat) Revascularization ${ }^{\mathrm{a}}, n(\%)$ & $183(7)$ & $150(12)$ & $6(1)$ & $27(5)$ & * \\
\hline NSTEMI/UA, $n$ & 1672 & 1014 & 331 & 327 & \\
\hline Duration of hospitalization in days (median, IQR) & $7(3-12)$ & $5(3-10)$ & $16(9-25)$ & $7(3-12)$ & * \\
\hline EuroSCORE (mean $\pm \mathrm{SD})$ & $5.8 \pm 2.8$ & $5.4 \pm 2.6$ & $6.1 \pm 3.2$ & $6.5 \pm 2.8$ & * \\
\hline 30 day mortality, $n(\%)$ & $35(2)$ & $19(2)$ & $8(2)$ & $8(2)$ & \\
\hline Total mortality at 1 year, $n(\%)$ & $82(5)$ & $41(4)$ & $17(5)$ & $24(7)$ & \\
\hline Non-fatal $M \mathrm{I}^{\mathrm{b}}, n(\%)$ & $43(3)$ & $30(4)$ & $11(4)$ & $2(1)$ & \\
\hline Rehospitalization for cardiac reason ${ }^{\mathrm{b}}, n(\%)$ & $376(29)$ & $249(31)$ & $48(19)$ & $78(31)$ & * \\
\hline (Repeat) Revascularization ${ }^{\mathrm{b}}, n$ (\%) & $133(10)$ & $119(14)$ & $5(2)$ & $9(3)$ & * \\
\hline STEMI, $n$ & 906 & 710 & 88 & 108 & \\
\hline Duration of hospitalization in days (median-IQR) & $7(4-12)$ & $7(4-11)$ & $13(9-27)$ & $9(4-18)$ & * \\
\hline 30 day mortality, $n(\%)$ & $42(5)$ & $30(4)$ & $7(8)$ & $5(5)$ & \\
\hline Total mortality at 1 year, $n(\%)$ & $67(7)$ & $51(7)$ & $7(8)$ & $9(8)$ & \\
\hline Non-fatal Mlc, $n(\%)$ & $18(3)$ & $13(3)$ & $2(3)$ & $3(4)$ & \\
\hline Rehospitalization for cardiac reason $^{c}, n(\%)$ & $148(23)$ & $122(24)$ & $7(11)$ & $19(24)$ & \\
\hline (Repeat) Revascularization ${ }^{c}, n(\%)$ & $63(9)$ & $58(11)$ & 0 & $5(6)$ & \\
\hline
\end{tabular}

allocation (Table 5). When coronary stenting was performed, 94\% were discharged on clopidogrel or ticlopidine. Other prophylactic drug classes such as beta-blockers, angiotensin-converting enzyme-inhibitors (ACE-inhibitors), and statins were used less frequently. Except for beta-blockers, comparison between the three treatment groups revealed significant differences in prescription profile. At 1 year follow-up, pharmacological treatment remained unchanged and below the target. Only the use of statins increased from discharge (54\%) to 1 year in patients undergoing CABG (69\%), but remained below the target.

\section{Discussion}

Acute presentations of CAD represented the primary indication for diagnostic angiography in $46 \%$ of all cases, whereas in patients with stable angina, the selection of patients to undergo diagnostic angiography was based on symptomatic status and/or risk evaluation. In line with previous reports, we observed a global normalcy rate of $24 \% .^{10,15}$ This proportion was higher when the primary diagnosis leading to the angiography was stable angina rather than acute CAD. An indication for mechanical revascularization followed the diagnostic angiogram in $57 \%$ of all cases screened and in $79 \%$ of those with at least one significant stenosis, indicating appropriate use of this invasive and expensive diagnostic procedure. This survey of current practice in Europe shows a clear preference for $\mathrm{PCl}$ over CABG (ratio 3:1), possibly suggesting under-use of the more invasive bypass operation. $^{16}$

In accordance with the guidelines, patients selected for CABG were sicker and had more extensive CAD; however, a sizable proportion of patients with multivessel or left main disease, impaired left ventricular function or diabetes did not undergo bypass surgery.

Patient and/or physician preference as well as the shorter time delay between angiography and $\mathrm{PCl}$ (compared with time delay between angiography and CABG) may have contributed to this choice. In patients with multi-vessel disease, recent meta-analyses show no difference in the rate of major irreversible adverse events between $\mathrm{PCl}$ and $\mathrm{CABG}{ }^{17,18}$ However, after 1 year follow-up, repeat $\mathrm{PCl}$ was performed in 10 and $3 \%$ eventually required $C A B G$, indicative of the lower durability of the result after $\mathrm{PCl}$. Coronary stenting using bare metal devices was applied in $72 \%$ of all segments and $\mathrm{PCl}$ was limited to a single-vessel in $82 \%$ of cases. Use of stents varied widely from $0 \%$ in two hospitals to $100 \%$ in 17 hospitals, a wide range that probably relates to differences in local reimbursement policies. It should be remembered that all data from the current survey have been acquired prior to the clinical availability of drug-eluting stents. Increased availability of these more durable devices will likely increase the confidence of interventional cardiologists in treating more complex patient and/or lesion subsets by means of $\mathrm{PCl} .{ }^{19}$ 
Table 5 Pharmacological treatment at discharge

\begin{tabular}{lllrrr}
\hline & Total $(n=5619)$ & PCI $(n=3254)$ & CABG $(n=1188)$ & Medical $(n=1177)$ & $P$-value \\
\hline Aspirin, $n(\%)$ & $4857(86)$ & $2972(91)$ & $922(78)$ & $963(82)$ & $*$ \\
Any anti-thrombotic drug, $n(\%)^{\text {a }}$ & $5356(95)$ & $3179(98)$ & $1087(92)$ & $1090(93)$ & $*$ \\
Beta-blocker, $n(\%)$ & $4133(74)$ & $2442(75)$ & $833(70)$ & $858(73)$ & 7 \\
ACE-inhibitor, $n(\%)$ & $3190(57)$ & $1845(57)$ & $590(50)$ & $755(64)$ & $*$ \\
Statin, $n(\%)$ & $3740(67)$ & $2301(71)$ & $643(54)$ & $796(68)$ & $*$ \\
\hline
\end{tabular}

Asterisks denote $P \leq 0.001$.

${ }^{a}$ Any anti-thrombotic drug includes anti-platelet drugs and coumadin.

Another proportion of patients who were at high risk did not undergo revascularization. This probably results from the limitations of currently available mechanical revascularization procedures in treating diffuse disease or from the poor general condition of some patients unable to undergo an invasive treatment or from the estimated unacceptably high procedural risks.

Despite their proven beneficial effects in high-risk patients (e.g. diabetes) and/or procedures, ${ }^{20,21}$ overall a sizable proportion of patients fulfiling these criteria did not receive GP IIb/IIla receptor blockers. In addition, major variations across European hospitals in the use of GP IIb/IIla receptor blockers were observed. Most surprising was the low use of these drugs in diabetic patients undergoing $\mathrm{PCl}$ for stable angina (15\%). Also of concern was the failure to measure post-procedural necrosis markers in $39 \%$ of all $\mathrm{PCl}$ procedures. Increased levels of cardiac enzymes are indeed an independent predictor of cardiac mortality and subsequent myocardial infarction. ${ }^{22,23}$ Similarly, in patients undergoing CABG, necrosis markers were measured in only one-third, most likely reflecting the disputable value of these markers following surgery. ${ }^{24}$

As to the treatment of STEMI, this survey concurs with previous studies in showing that reperfusion treatment remains underused, ${ }^{25}$ even in this selected subgroup of patients referred for angiography. By design, we cannot analyse the factors that contribute to this sobering observation. In accordance with the guidelines, primary $\mathrm{PCl}$ is the preferred treatment for STEMI, provided this procedure can be performed by an experienced team within 90 min after first medical contact. ${ }^{9}$ It was encouraging to observe that the majority of patients undergoing primary $\mathrm{PCl}$ was treated within the advocated timeframe of $90 \mathrm{~min}$. However, due to missing admission or procedure times, the in-hospital delay was unknown in a sizeable proportion of patients. The current prospective survey clearly shows that in clinical practice, reporting of all relevant time intervals was not optimal. This failure stresses the importance of a thorough registration as well as the need for implementing in each institution appropriate procedures and pathways that will permit to select the optimal treatment for an individual patient. ${ }^{26,27}$

The overall mortality figures were low $(1.9 \%$ at 30 days and $4.7 \%$ at 1 year) in all patient groups and treatment modalities, even after risk-adjustment using for instance the EuroSCORE. As expected, 1 year mortality rate was larger in STEMI (7\%) and in NSTEMI/UA (5\%) compared with stable angina patients (3\%).

Patients with established CAD enrolled in this survey should benefit from secondary prevention measures. ${ }^{28}$ Changing the patient risk behaviour (unhealthy diet, smoking, and sedentary lifestyle) and prescribing drugs with proven prophylactic effects are essential aspects of current treatment, even after mechanical revascularization. $^{29-33}$ Furthermore, effective secondary prevention in clinical practice, using evidence-based treatment, has been proven effective in reducing the composite of death, myocardial infarction, and stroke. ${ }^{34,35}$ Although the majority of patients used antithrombotics and beta-blockers, as recommended, ACEinhibitors were underused in all subgroups and statins were particularly underused after CABG. Overall, prescription of these prophylactic drugs was increased when compared with EuroAspire II, ${ }^{36}$ indicating that time is required before guidelines are progressively endorsed. In any case, the moment that patients are admitted in the hospital to undergo an invasive procedure should be taken as an opportunity to further optimize their pharmacological treatment.

The limitations of this study are those inherent to observational surveys involving voluntarily participating hospitals. Although we have attempted to include a wide spectrum of hospitals in different countries, almost certainly the results are biased towards better than average practices. The sample size only represents a small fraction of all patients admitted in catheterization laboratories throughout Europe during the study period. Nevertheless, because patient inclusion was consecutive at the participating sites, we trust that the survey depicts the ongoing clinical practice. Data on the 1 year followup were not obtainable in 14 hospitals (from 10 countries) because of management problems unrelated to individual patient characteristics. Presumably, this did not introduce significant selection bias. Data quality was checked through queries for missing or contradictory entries. However, no site visits or source data verification was performed. However, since many participating sites are part of other Euro Heart Surveys, their performance is regularly evaluated.

To summarize, the current Euro Heart Survey on coronary revascularization provides a global European picture of the invasive approach to patients with CAD, as they present with either stable angina, STEMI or NSTEMI/UA. Although the recommendations of guidelines are mostly 
endorsed, the main area for improvement pertains to the underuse of adjunctive pharmacology (GP IIb/IIla inhibitors, statins, and ACE-inhibitors). These data on the indications for revascularization, the choice between $\mathrm{PCl}$ or CABG and their outcome in the era of bare metal stenting will serve as a benchmark for the future evaluation of the impact of drug-eluting stents on the practice of coronary revascularization.

\section{Appendix: Organization of the survey}

Coronary Revascularization Expert Committee: W. Wijns (Survey Chairman), Belgium; N. Mercado (Research Fellow), The Netherlands; M. Bertrand, France; W. Maier, Switzerland; B. Meier, Switzerland; C. Moris, Spain; F. Piscione, Italy; U. Sechtem, Germany; P. Sergeant, Belgium; E. Stahle, Sweden; J. Vos, The Netherlands; P. Widimsky, Czech Republic; F. Unger, Austria.

Euro Heart Survey Team (European Heart House, France): Malika Manini (Operations Manager); Claire Bramley (Data Monitor); Valérie Laforest (Data Monitor); Charles Taylor (Database Administrator); Susan Del Gaiso (Administrator).

National Coordinators: Austria, Kurt Huber; Belgium, Guy De Backer; Bulgaria, Vera Sirakova; Czech Republic, Roman Cerbak; Denmark, Per Thayssen; Finland, Seppo Lehto; France, Jean-Jacques Blanc, François Delahaye; Georgia, Bondo Kobulia; Germany, Uwe Zeymer; Greece, Dennis Cokkinos; Hungary, Kristof Karlocai; Ireland, Ian Graham, Emer Shelley; Israel, Shlomo Behar; Italy, Aldo Maggioni; Lithuania, Virginija Grabauskiene; The Netherlands, Jaap Deckers; Norway, Inger Asmussen; Poland, Janina Stepinska; Portugal, Lino Gonçalves; Russia, Vyacheslav Mareev; Slovakia, Igor Riecansky; Slovenia, Miran F. Kenda; Spain, Angeles Alonso, José Luis Lopez-Sendon; Sweden, Annika Rosengren; Switzerland, Peter Buser; Turkey, Tugrul Okay; Ukraine, Oleg Sychov; United Kingdom, Kevin Fox.

Euro Heart Survey Board Committee: David Wood (Chairman), United Kingdom; Angeles Alonso, Spain; Shlomo Behar, Israel; Eric Boersma, The Netherlands; Harry Crijns, The Netherlands; Kim Fox, United Kingdom; Malika Manini, France; Keith McGregor, France; Barbara Mulder, The Netherlands; Sylvia Priori, Italy; Lars Rydén, Sweden; Luigi Tavazzi, Italy; Alec Vahanian, France; Panos Vardas, Greece; William Wijns, Belgium; Uwe Zeymer, Germany.

Industry Sponsor: Eucomed.

List of Sponsoring Institutions: French Federation of Cardiology, Hellenic Cardiological Society, Netherland Heart Foundation, Swedish Heart and Lung Foundation, and individual hospitals.

Participating Centres, Investigators, and Data Collection Officers: Armenia: Karine Sarkisyan, Yerevan. Austria: H.D. Glogar, Michael Derntl, Vienna; Matthias Frick, O. Pachinger, Ralf Zwick, Innsbruck. Belgium: Christiaan Vrints, Els Van Hertbruggen, Marc Vercammen, Tineke Sysmans, Edegem; E. Schroeder, Juliette Domange, Yvoir; William Wijns, Hilde De Pril, Aalst; Johan De Vriese, Tonny Van Hecke, Gent; V. Legrand, Marie-France Gillon, Michel Richardy, P. Doneux, Liege. Bulgaria: Ivo Petrov, J. Jorgova, Sofia; Vera Sirakova, Varna. Croatia: Boris Starcevic, Zagreb. Switzerland: Eric Eeckhout, Alexandre Berger, Veronique Prudent, Lausanne; E. Camenzind, Nicolas Masson, Geneve. Cyprus: Costas Zambartas, Helen Kleanthous, Nicosia. Czech Republic: Petr Widimsky, Blanka Stellova, Michael Aschermann, Stanislav
Simek, J. Kautzner, Vladimir Karmazin, P. Svab, Prague; Jan Indrak, M. Branny, Trinec; Kveta Hladilova, P. Kala, Brno. Denmark: P. Thayssen, Helle Cappelen, Lisette Okkels Jensen, Odense. Germany: A. Gitt, Konstanze Gehrke, Ludwigshafen am Rhein; R. Erbel, Achim Gutersohn, Holger Eggebrecht, Murad Al Khani, Essen; Udo Sechtem, Antje Rosenberger, Holger Vogelsberg, Stuttgart; H. Klepzig, Arnold Schmidt, Offenbach; Sigmund Silber, Birgit Mau, Munich; Christian Leuner, Karen Czyborra, Bielefeld; Christina Reuschling, Eva Muno, Bad Nauheim; F. Kleber, Sascha Rux, Berlin; U. Zeymer, Kassel. Egypt: Aly Saad, Zagazig; BSS. Ibrahim, Maged Elabady, Cairo. Spain: A. Castro Beiras, Jorge Salgado Fernandez, La Coruna; Felipe Navarro del Arno, A. Iniguez Romo, Madrid; J.M. Cruz Fernandez, Alejandro Recio Mayoreal, Franciso Javier Rivero Rebanal, Mariano Garcia de la Borbolla, Marinela Chaparro, Sevilla; C. Brotons, C. Permanyer Miralda, Srta Irma Vila i Perez, Barcelona; Cesar Moris, Oviedo; F. Fernandez Aviles, Luis de la Fuente Galan, Paula Tejedor Vinuela, Valladolid; F. Malpartida de Torres, Javier Mora, Malaga; Ignacio Santos Rodriguez, Itziar Piedra Bustamante, Pedro L. Sanchez Fernandez, Salamanca; J.L. Diago Torrent, Jose L. Diez Gil, Castellon; Javier Perpinan, V. Palacios Motilla, Alzira, Valencia; M. Soledad Alcasena Juango, Jesus Berjon-Reyero, Pamplona; R. Melgares Moreno, Juan Carlos Fernandez Guerrero, Granada. Finland: S. Lehto, Kirsti Savolainen, Kuopio; MS. Nieminen, Mikko Syvanne, Helsinki. France: A. Cohen-Solal, Antoine-Sylvain Oboa, Clichy; J.P. Bassand, Denis Pales Espinosa, Veronique Jouet, Besancon Cedex; G. Montalescot, Vanessa Gallois, Paris; J.C. Daubert, Jean Michel Clerc, Rennes; Jacques Machecourt, Grenoble; Y. Cottin, Dijon. United Kingdom: D. Walker, Fhiona Holland, St Leonards-onSea; D. Wood, Jenni Prosser, Lis Muir, Kate Barber, London; J.G.F. Cleland, Jocelyn Cook, Kingston upon Hull. Georgia: Bondo Kobulia, Zaza Chapichadze, Tbilisi. Greece: Ioannis Skoularigisn Athanasiou Christos, Larisa; Dennis Cokkinos, Nastasia Tsiavou, Christina Chrysohoou, Athanassios Manginas, John Terrovitis, John Kanakakis, Manolis Vavuranakis, Stavros Drakos, Athens; Thomas Farmakis, C. Samara, Thessaloniki; Christina Papakosta, Christos Bourantas, L.K. Michalis, Mpourantas Christos, Ioannina; Stefanos Foussas, Evdokia Adamopoulou, Pireus; P.E. Vardas, Mary Marketou, Heraklion, Crete. Hungary: N. Alotti, Anna Maria Basa, Andras Vigh, Zalaegerszeg; Istvan Preda, Eva Csoti, M. Keltai, G. Kerkovits, Budapest. Israel: Alberto Hendler, Alex Blatt, Beer Yakov; R. Beyar, Arie Shefer, David Halon, Margalait Bentzvi, Naomi Avramovitch, Haifa; Avinoam Bakst, Kfar Saba; Carlos Cafri, Aviva Grosbard, Beer Sheva; Bella Margolis, Khalid Suleiman, Afula; Shmuel Banai, David Meerkin, Morris Mosseri, Pnina Guita, Rifat Jabara, Jerusalem; Jamal Jafari, Debi Ben Shitrit, Ashkelon; Dr Ghasan, Dr Salameh, Tiberias; Marc Brezins, Lily van den Akker-Berman, Nahariya; Victor Guetta, Tel Hashomer; Yoseph Rozenman, Holon. Italy: A. Biagini, Sergio Berti, Massa; Massimo Ferrero, A. Colombo, R. Roccaforte, Caterina Milici, Milano; L. Scarpino, A. Salvi, Gorizia; Alessandro Desideri, Daniela Sabbadin, Castelfranco Veneto; Alfredo Galassi, Giuseppe Giuffrida, Catania; Andrea Rognoni, Corrado Vassanelli, Paola Paffoni, Novara; Angelo Cioppa, Paolo Rubino, Mercogliano (Avellino); Marco de Carlo, Anna Sonia Petronio, Pisa; F. Naccarella, Francesco Saia, Antonio Marzocchi, Stefano Sdringola Maranga, Bologna; P. Presbitero, Fazya Valsecchi, Rozzano-Milan; Federico Piscione, Giovanni Esposito, Napoli M. Santini, Marco Tubaro, Rome. Lithuania: A. Erglis, Inga Narbute, Riga; Ausra Kavoliuniene, R. Zaliunas, Ramunas Navickas, Kaunas; V. Grabauskiene, Davia Luckute, Eduardas Subkovas, Vilnius. Luxembourg: Daniel Wagner. The Netherlands: F. Vermeer, Aimee Lousberg, Heidi Fransen, Maastricht; Arno Breeman, Henriette Tebbe, M.J. De Boer, 
Metske van der Wal, Zwolle; J. Deckers, Jeroen Vos, C.M. Leenders, M.J. Veerhoek, Chris Jansen, Rotterdam; M. Bijl, Colinda Koppelaar, Dordrecht; Dr Van den Linden, Colinda Koppelaar, Vlaardingen; R. Brons, Henriette Tebbe, Meppel; J.W.M.G. Widdershofen, Herman Broers, Tilburg. Norway: F. Kontny, Marianne Jonzon, Oslo. Poland: Jan Wodniecki, Andrzej Tomasik, Zabrze; M. Trusz-Gluza, Seweryn Nowak, Katowice; Witold Ruzyllo, Tomasz Deptuch, Warsaw. Portugal: Jorge Marques, F. Matias, Almada; H. Madeira, Joaquim Oliveira, Luis Sargento, Lisbon. Romania: Adina Ionac, losif Stefan Dragulescu, Bogdan Mut-Vitcu, Daniela Maximov, Timisoara; M. Dorobantu, E. Apetrei, Rodica Niculescu, Virgil Petrescu, Adrian Bucsa, Dan Deleanu, Bucharest; I.S. Benedek, Theodora Hintea, Targu-Mures. Russian Federation: D. Aronov, Elena Tikhomirova, Moscow. Slovenia: I. Kranjec, Katja Prokselj, Ljubljana; Vojko Kanic, Maribor. Turkey: Tugrul Okay, Ahmet Sepetoglu, Istanbul; S. Aytekin, V. Aytekin, Alp Burak Catakoglu, Hayri Parlar, Suavi Tufekcioglu, Zeki Ozyedek, Sisli; Mehmet Baltali, Dr Kiziltan, Adana. Serbia \& Montenegro: Milan Vukovic, A.N. Neskovic, Belgrade.

\section{References}

1. Braunwald E. Cardiovascular medicine at the turn of the millennium: triumphs, concerns, and opportunities. N Engl J Med 1997; 337:1360-1369.

2. Scandinavian Simvastatin Survival Study Group. Randomised trial of cholesterol lowering in $\mathbf{4 4 4 4}$ patients with coronary heart disease: the Scandinavian Simvastatin Survival Study (4S). Lancet 1994; 344:1383-1389.

3. ISIS-4. A randomised factorial trial assessing early oral captopril, oral mononitrate, and intravenous magnesium sulphate in 58050 patients with suspected acute myocardial infarction. Lancet 1995; 345:669-682.

4. Yusuf SLJ, Jha P, Lonn E. Primary and secondary prevention of myocardial infarction and strokes: an update of randomly allocated, controlled trials. J Hypertens Suppl 1993;11:S61-S73.

5. Cleland JGF. For debate: preventing atherosclerotic events with aspirin. BMJ 2002;324:103-105.

6. Serruys PW, Unger F, Sousa JE, Jatene A, Bonnier HJRM, Schonberger JPAM, Buller N, Bonser R, van den Brand MJB, van Herwerden LA, Morel M-AM, van Hout BA. The Arterial Revascularization Therapies Study Group. Comparison of coronary-artery bypass surgery and stenting for the treatment of multivessel disease. $N$ Engl $J$ Med 2001;344:1117-1124.

7. Management of stable angina pectoris. Recommendations of the Task Force of the European Society of Cardiology. Eur Heart J 1997; 18:394-413.

8. Bertrand MESM, Fox KA, Wallentin LC, Hamm CW, McFadden E, De Feyter PJ, Specchia G, Ruzyllo W. Task Force on the Management of Acute Coronary Syndromes of the European Society of Cardiology. Management of acute coronary syndromes in patients presenting without persistent ST-segment elevation. Eur Heart J 2002; 23:1809-1840.

9. van de Werf F, Ardissino D, Betriu A, Cokkinos DV, Falk E, Fox KAA, Julian D, Lengyel M, Neumann FJ, Ruzyllo W, Thygesen C, Underwood SR, Vahanian A, Verheugt FWA, Wijns W. Management of acute myocardial infarction in patients presenting with ST-segment elevation. Eur Heart J 2003;24:28-66.

10. Boersma HDG, Bloemberg BPM, Wood DA, Kromhout D, Simoons ML. Cardiovascular diseases in Europe. European registries of cardiovascular diseases and patient management. Sophia Antipolis: European Society of Cardiology 1999. Available from escardio.org

11. Campeau L. Letter: grading of angina pectoris. Circulation 1976; 54:522-523.

12. Gibbons RJ, Chatterjee K, Daley J, Douglas JS, Fihn SD, Gardin JM, Grunwald MA, Levy D, Lytle BW, O'Rourke RA, Schafer WP, Williams SV, Ritchie JL, Cheitlin MD, Eagle KA, Gardner TJ, Garson A Jr, Russell RO, Ryan TJ, Smith SC Jr. et al. ACC/AHA/
ACP-ASIM guidelines for the management of patients with chronic stable angina: a report of the American College of Cardiology/American Heart Association Task Force on Practice Guidelines (Committee on Management of Patients With Chronic Stable Angina). J Am Coll Cardiol 1999;33:2092-2197.

13. Nashef SA, Roques F, Michel P, Gauducheau E, Lemeshow S, Salamon R. European system for cardiac operative risk evaluation (EuroSCORE). Eur J Cardiothorac Surg 1999;16:9-13.

14. Antman EM, Cohen M, Bernink PJ, McCabe CH, Horacek T, Papuchis G, Mautner B, Corbalan R, Radley D, Braunwald E. The TIMI risk score for unstable angina/non-ST elevation MI: a method for prognostication and therapeutic decision making. JAMA 2000;284:835-842.

15. Maier W, Enderlin MF, Bonzel T, Danchin N, Heyndrickx G, Muhlberger V, Neuhaus KL, Piscione F, Reifart N, Antoni J, Ogurol Y, Wischnewsky $M B$, Meier B. Audit and quality control in angioplasty in Europe: procedural results of the AQUA Study 1997: assessment of 250 randomly selected coronary interventions performed in 25 centres of five European countries. Eur Heart J 1999;20:1261-1270.

16. Hemingway H, Crook AM, Feder G, Banerjee S, Dawson JR, Magee P, Philpott S, Sanders J, Wood A, Timmis AD. Underuse of coronary revascularization procedures in patients considered appropriate candidates for revascularization. N Engl J Med 2001;344:645-654.

17. Pocock SJ, Henderson RA, Rickards AF, Hampton JR, King SB III, Hamm CW, Puel J, Hueb W, Goy JJ, Rodriguez A. Meta-analysis of randomised trials comparing coronary angioplasty with bypass surgery. Lancet 1995;346:1184-1189.

18. Mercado N, Wijns W, Serruys PW, Sigwart U, Flather MD, Stables RH, O'Neill WW, Rodriguez A, Lemos PA, Hueb WA, Gersh BJ, Booth J, Boersma E. One-year outcomes of coronary artery bypass graft surgery versus percutaneous coronary intervention with multiple stenting for multisystem disease: a meta-analysis of individual patient data from randomized clinical trials. J Thorac Cardiovasc Surg 2005, in press.

19. Lemos PA, Serruys PW, van Domburg RT, Saia F, Arampatzis CA, Hoye A, Degertekin M, Tanabe K, Daemen J, Liu TK, McFadden E, Sianos G, Hofma SH, Smits PC, van der Giessen WJ, de Feyter PJ. Unrestricted utilization of sirolimus-eluting stents compared with conventional bare stent implantation in the "real world": the Rapamycin-Eluting Stent Evaluated At Rotterdam Cardiology Hospital (RESEARCH) registry. Circulation 2004;109:190-195.

20. Boersma E, Harrington RA, Moliterno DJ, White H, Theroux P, van de Werf F, de Torbal A, Armstrong PW, Wallentin LC, Wilcox RG, Simes J, Califf RM, Topol EJ, Simoons ML. Platelet glycoprotein Ilb/Illa inhibitors in acute coronary syndromes: a meta-analysis of all major randomised clinical trials. Lancet 2002;359:189-198.

21. Roffi M, Chew DP, Mukherjee D, Bhatt DL, White JA, Heeschen C, Hamm CW, Moliterno DJ, Califf RM, White HD, Kleiman NS, Theroux P, Topol EJ. Platelet glycoprotein Ilb/IIla inhibitors reduce mortality in diabetic patients with non-ST-segment-elevation acute coronary syndromes. Circulation 2001;104:2767-2771.

22. Smith SC Jr, Dove JT, Jacobs AK, Kennedy JW, Kereiakes D, Kern MJ, Kuntz RE, Popma JJ, Schaff HV, Williams DO, Gibbons RJ, Alpert JP, Eagle KA, Faxon DP, Fuster V, Gardner TJ, Gregoratos G, Russell RO, Smith SC Jr. American College of Cardiology; American Heart Association Task Force on Practice Guidelines. Committee to Revise the 1993 Guidelines for Percutaneous Transluminal Coronary Angioplasty. ACC/AHA guidelines of percutaneous coronary interventions (revision of the 1993 PTCA guidelines)-executive summary. A report of the American College of Cardiology/American Heart Association Task Force on Practice Guidelines (committee to revise the 1993 guidelines for percutaneous transluminal coronary angioplasty). J Am Coll Cardiol 2001;37:2215-2239.

23. Kong TQ, Davidson CJ, Meyers SN, Tauke JT, Parker MA, Bonow RO. Prognostic implication of creatine kinase elevation following elective coronary artery interventions. JAMA 1997;277:461-466.

24. Eagle KA, Guyton RA, Davidoff R, Edwards FH, Ewy GA, Gardner TJ, Hart JC, Herrmann HC, Hillis LD, Hutter AM Jr, Lytle BW, Marlow RA, Nugent WC, Orszulak TA. American College of Cardiology; American Heart Association. ACC/AHA 2004 guideline update for coronary artery bypass graft surgery: a report of the American College of Cardiology/American Heart Association Task Force on Practice Guidelines (Committee to Update the 1999 Guidelines for Coronary Artery Bypass Graft Surgery). Circulation 2004;110:e340-e437. 
25. Hasdai D, Behar S, Wallentin L, Danchin N, Gitt AK, Boersma E, Fioretti PM, Simoons ML, Battler A. A prospective survey of the characteristics, treatments and outcomes of patients with acute coronary syndromes in Europe and the Mediterranean basin; the Euro Heart Survey of Acute Coronary Syndromes (Euro Heart Survey ACS). Eur Heart J 2002;23:1190-1201.

26. Mehta RH, Montoye CK, Faul J, Nagle DJ, Kure J, Raj E, Fattal P, Sharrif S, Amlani M, Changezi HU, Skorcz S, Bailey N, Bourque T, LaTarte M, McLean D, Savoy S, Werner P, Baker PL, DeFranco A, Eagle KA. American College of Cardiology Guidelines Applied in Practice Steering Committee. Enhancing quality of care for acute myocardial infarction: shifting the focus of improvement from key indicators to process of care and tool use: the American College of Cardiology Acute Myocardial Infarction Guidelines Applied in Practice Project in Michigan: Flint and Saginaw Expansion. J Am Coll Cardiol 2004;43:2166-2173.

27. Mukherjee D, Eagle KM. Improving quality of care in the real world: efficacy versus effectiveness? Am Heart J 2003;146:946-947.

28. De Backer G, Ambrosioni E, Borch-Johnsen K, Brotons C, Cifkova R, Dallongeville J, Ebrahim S, Faergeman O, Graham I, Mancia G, Manger Cats V, Orth-Gomer K, Perk J, Pyorala K, Rodicio JL, Sans S, Sansoy V, Sechtem U, Silber S, Thomsen T, Wood D. Third Joint Task Force of European and Other Societies on Cardiovascular Disease Prevention in Clinical Practice. European guidelines on cardiovascular disease prevention in clinical practice. Third Joint Task Force of European and Other Societies on Cardiovascular Disease Prevention in Clinical Practice. Eur Heart J 2003;24:1601-1610.

29. Arnold JM, Yusuf S, Young J, Mathew J, Johnstone D, Avezum A, Lonn E, Pogue J, Bosch J, HOPE Investigators. Prevention of Heart Failure in Patients in the Heart Outcomes Prevention Evaluation (HOPE) Study. Circulation 2003;107:1284-1290.

30. Serruys PW, de Feyter P, Macaya C, Kokott N, Puel J, Vrolix M, Branzi A, Bertolami MC, Jackson G, Strauss B, Meier B. Lescol Intervention Prevention Study (LIPS) Investigators. Fluvastatin for prevention of cardiac events following successful first percutaneous coronary intervention: a randomized controlled trial. JAMA 2002;287:3215-3222.

31. Fox KM. EURopean trial on reduction of cardiac events with perindopril in stable coronary artery disease Investigators. Efficacy of perindopril in reduction of cardiovascular events among patients with stable coronary artery disease: randomised, double-blind, placebocontrolled, multicentre trial (the EUROPA study). Lancet 2003;362:782-788.

32. Peters RJ, Mehta SR, Fox KA, Zhao F, Lewis BS, Kopecky SL, Diaz R, Commerford PJ, Valentin V, Yusuf S, Clopidogrel in Unstable angina to prevent Recurrent Events (CURE) Trial Investigators. Effects of aspirin dose when used alone or in combination with clopidogrel in patients with acute coronary syndromes: observations from the Clopidogrel in Unstable angina to prevent Recurrent Events (CURE) study. Circulation 2003;108:1682-1687.

33. Budaj A, Brieger D, Steg PG, Goodman SG, Dabbous OH, Fox KA, Avezum A, Cannon CP, Mazurek T, Flather MD, Van De Werf F, GRACE Investigators. Global patterns of use of antithrombotic and antiplatelet therapies in patients with acute coronary syndromes: insights from the Global Registry of Acute Coronary Events (GRACE). Am Heart J 2003;146:999-1006.

34. Chan AW, Bhatt DL, Chew DP, Quinn MJ, Moliterno DJ, Topol EJ, Ellis SG. Early and sustained survival benefit associated with statin therapy at the time of percutaneous coronary intervention. Circulation 2002;105:691-696.

35. Mukherjee D, Lingam P, Chetcuti S, Grossman PM, Moscucci M, Luciano AE, Eagle KA. Missed opportunities to treat atherosclerosis in patients undergoing peripheral vascular interventions: insights from the University of Michigan Peripheral Vascular Disease Quality Improvement Initiative (PVD-QI2). Circulation 2002;106:1909-1912.

36. EUROASPIRE II Study Group. Lifestyle and risk factor management and use of drug therapies in coronary patients from 15 countries; principal results from EUROASPIRE II Euro Heart Survey Programme. Eur Heart J 2001;22:554-572. 